\title{
Metabolism of 2-hydroxy-4-(methylthio)butanoate (HMTBA) in lactating dairy cows
}

\author{
H. Lapierre, ${ }^{\star 1}$ M. Vázquez-Añón,† D. Parker,† P. Dubreuil,‡ G. Holtrop,§ and G. E. Lobley\# \\ *Dairy and Swine Research \& Development Centre, Agriculture and Agri-Food Canada, STN Lennoxville, Sherbrooke, Quebec, Canada, J1M 1Z3 \\ †Novus International, St. Louis, MO 63304 \\ ‡Faculté de médecine vétérinaire, Université de Montréal, St-Hyacinthe, Quebec, Canada, J2S 7C6 \\ §Biomathematics and Statistics Scotland (BioSS), Aberdeen, AB21 9SB, UK \\ \#Rowett Institute of Nutrition and Heath, University of Aberdeen, Aberdeen, AB21 9SB, UK
}

\section{ABSTRACT}

The objectives of the current study were to determine the fate and contribution to Met kinetics of 2-hydroxy4-(methylthio)butanoate (HMTBA) at the whole-body, splanchnic, and mammary levels. Four multicatheterized cows $(31.3 \mathrm{~kg}$ of milk/d; $17.7 \mathrm{~kg}$ of $\mathrm{DMI} / \mathrm{d})$ were used in a crossover design, with two 1-wk periods, to determine the metabolic fate of HMTBA and its effect on Met metabolism. Over the last $2 \mathrm{~d}$ of each period, cows were infused, via a jugular vein, with saline or HMTBA (Alimet, Novus International Inc., St. Louis, $\mathrm{Mo}$ ) at the rate of $36 \mathrm{~g} / \mathrm{d}$. During the last $8 \mathrm{~h}$, the HMTBA infusion was substituted by equimolar $\left[1-{ }^{13} \mathrm{C}\right]$ HMTBA $(8.79 \mathrm{mmol} / \mathrm{h})$ and $\mathrm{L}\left[\right.$ methyl- $\left.^{2} \mathrm{H}_{3}\right]$ Met $(1.31$ $\mathrm{mmol} / \mathrm{h}$ ) was infused in all cows. During the last $5 \mathrm{~h}$, hourly samples $(\mathrm{n}=6)$ were collected to determine plasma flows plus the isotopic enrichments (IE) and concentrations of HMTBA $\left({ }^{13} \mathrm{C}\right)$ and Met (both ${ }^{13} \mathrm{C}$ and $\left.{ }^{2} \mathrm{H}_{3}\right)$ in plasma from an artery plus portal, hepatic, and mammary veins. The IE of $\left[{ }^{13} \mathrm{C}\right]$ and $\left[{ }^{2} \mathrm{H}_{3}\right]$ Met were also determined in milk protein taken over the last $1 \mathrm{~h}$ of infusion in HMTBA-infused cows. The infused HMTBA increased whole-body plasma flux of Met by $6.5 \mathrm{mmol} / \mathrm{h}$ (from 17.9 to $24.4 \mathrm{mmol} / \mathrm{h}$ ). Based on enrichments of ${ }^{13} \mathrm{C}$-labeled Met, $3.8 \mathrm{mmol} / \mathrm{h}$ of Met flow through plasma was derived directly from HMTBA. These 2 estimates accounted for between 43 to $74 \%$ of the HMTBA dose infused, contributing to increased whole-body Met availability. Although the portal-drained viscera, liver, and mammary gland (MG) extracted 11,37 , and $3.4 \%$, respectively, of the infused HMTBA, tissue net Met fluxes were either unchanged (portal-drained viscera, MG) or even reduced (liver: -7.9 vs. $-2.4 \pm 0.6 \mathrm{mmol} / \mathrm{h}$ ). Therefore, net postsplanchnic supply of Met decreased from 7.0 to 2.9 $\mathrm{mmol} / \mathrm{h}$ between control and HMTBA-infused cows,

Received October 8, 2010.

Accepted November 5, 2010.

${ }^{1}$ Corresponding author: Helene.Lapierre@agr.gc.ca compared with needs for milk protein secretion of 7.6 and $8.1 \mathrm{mmol} / \mathrm{h}$, respectively. The HMTBA provided directly $15 \%$ of the Met required for milk protein secretion, with $0.2 \mathrm{mmol} / \mathrm{h}$ synthesized within the $\mathrm{MG}$, whereas $1.1 \mathrm{mmol} / \mathrm{h}$ originated from Met produced in other tissues and transported to the MG through blood circulation. Most of the remainder needed by the MG arose from unlabeled Met released from protein breakdown in extra-splanchnic tissues and that was not reused to support intracellular protein synthesis, as this function was performed by Met synthesized from HMTBA in situ. Absorbed HMTBA, therefore, both produces and spares Met for use by the MG.

Key words: analog, methionine, splanchnic, mammary

\section{INTRODUCTION}

The hydroxy analog of methionine, 2-hydroxy-4(methylthio)butanoate (HMTBA), has long been proposed as a means to provide Met and increase milk and protein yields of dairy cows fed rations limited in Met (Polan et al., 1970). The analog HMTBA is more resistant to rumen microbial degradation than L-Met (Belasco, 1972), but estimations of postrumen availability of HMTBA vary greatly. In dairy cows, between $5 \%$ (Noftsger et al., 2005) and 50\% (Koenig et al., 1999,2002 ) of the ingested dose was reported to flow postrumen. Direct measures of net portal absorption of HMTBA averaged $13 \%$ of the ingested dose (Lapierre et al., 2007), although this is an underestimate that does not account for any conversion to Met or metabolism by gut tissues (McCollum et al., 2000; Lobley et al., 2006b). In practice, the effectiveness of HMTBA in dairy cow husbandry depends not only on the amount absorbed across the gastrointestinal tract but also on the metabolic conversion to Met by body tissues. Most previous studies have focused on the former aspect and few data are available on the fate of HMTBA absorbed by ruminants.

The HMTBA feed supplement is a racemic mixture of D- and L-isomers that can both be converted to 2-oxo- 
4-methylthiobutanoate (also produced by deamination of D-Met) followed by amination to L-Met. The oxidase for L-HMTBA exists predominantly in the peroxisomes within liver and kidney, whereas the dehydrogenase for D-HMTBA is a mitochondrial enzyme found in most tissues (Dibner and Knight, 1984; McCollum et al., 2000; Dibner, 2003). Despite this wide distribution of tissue enzyme activities, most of the studies conducted in chickens have focused their attention at studying the liver as the site of both removal (Wang et al., 2001) and metabolism of HMTBA (Dibner and Ivey, 1992). However, recent studies in ruminants have shown that conversion of HMTBA to L-Met does occur across a range of tissues both in vitro (McCollum et al., 2000) and in vivo (Lobley et al., 2006a). For example, for sheep infused with labeled HMTBA, all tissues studied synthesized Met, but to different extents, with the highest rates for liver and kidney. Interestingly, most of the newly synthesized Met exported into the circulation was derived from renal metabolism (Lobley et al., 2006a,b). Although the ovine liver extracted $25 \%$ of the absorbed HMTBA, the net hepatic flux of Met decreased with HMTBA supplementation. This was despite increases in both plasma concentrations and whole-body flux for Met, indicating both production and release of Met derived from HMTBA in peripheral (nonhepatic) tissues (Wester et al., 2006). In dairy cows, the liver also extracted a considerable proportion (34\%) of absorbed HMTBA (Lapierre et al., 2007), but no evaluation of the concomitant effect on Met kinetics was conducted. Indeed, there are no reports on the metabolic fate of HMTBA in dairy cows, where the demand for Met is exacerbated to sustain milk protein yield.

Therefore, the objectives of the current study were to determine the fate of HMTBA at the whole-body level and across both splanchnic and mammary tissues and the contribution to Met kinetics across these organs.

\section{MATERIALS AND METHODS}

\section{Animals and Treatments}

Four cows, averaging $650 \pm 92(\mathrm{SD}) \mathrm{kg}$ and $131 \pm$ 12 DIM at the beginning of the study, were used in a randomized crossover design with two 1-wk experimental periods. Cows had been implanted, at least 4 mo before the start of the project, with catheters into the portal vein, one hepatic vein, and the caudal aorta via a mesenteric artery for blood sampling and in 2 distal mesenteric veins for para-amino hippuric acid $(\boldsymbol{p} \mathbf{A H})$ infusion to determine splanchnic blood flow (Huntington et al., 1989). Cows were fed a fixed amount of TMR every $2 \mathrm{~h}$ in equal meals plus $1 \mathrm{~kg}$ of hay/d (Tables 1 and 2 ). The diet was balanced to provide sufficient crude, degradable and nondegradable protein, energy, and MP, but with Met contributing only $1.83 \%$ of MP and, therefore, estimated as deficient (NRC, 2001; Table 1). The cows were kept in a tie-stall barn and were milked twice per day, at 12-h intervals. During the last $2 \mathrm{~d}$ of each experimental period, one jugular vein of each cow was infused with either saline (control) or unlabeled HMTBA (1.5 g/h; Alimet, Novus International Inc., St. Louis, MO; $88 \%=8.79 \mathrm{mmol} / \mathrm{h})$. During the last $8 \mathrm{~h}$ of infusion, the jugular vein of each cow was infused with $\mathrm{L}\left[\right.$ methyl- $\left.{ }^{2} \mathrm{H}_{3}\right] \mathrm{Met}(1.31 \mathrm{mmol} / \mathrm{h})$ and over the same period when cows received unlabeled HMTBA, this was substituted by $\left[1-{ }^{13} \mathrm{C}\right]$ HMTBA (also at $8.79 \mathrm{mmol} / \mathrm{h}$ ). In order to determine the concentrations and the isotopic enrichment (IE) of HMTBA $\left({ }^{13} \mathrm{C}\right.$-HMTBA), Met $\left({ }^{13} \mathrm{C}\right.$ and ${ }^{2} \mathrm{H}_{3}$-Met $)$, and $\left[{ }^{13} \mathrm{C}\right]$ bicarbonate in the arterial, portal, hepatic, and mammary plasma, hourly blood samples were simultaneously collected from arterial, portal, hepatic, and mammary sources from 3 to $8 \mathrm{~h}$ of the infusion of labeled Met. Mammary blood samples were collected by venipuncture. In addition, the cows were milked 7 and $8 \mathrm{~h}$ after the initiation of the labeled Met infusion, with each milking conducted following oxytocin injection. Milk was sampled at this last milking for determination of the enrichment of Met in CN in HMTBA-infused cows. During the sampling period, $p \mathrm{AH}(14.4 \mathrm{~g} / \mathrm{h}$ preceded by a priming dose of $2 \mathrm{~g})$ was infused into the mesenteric vein of cows, beginning at least $40 \mathrm{~min}$ before the first blood sample. Prior to the initiation of the infusions of labeled material, blood samples were collected from all of the vessels to determine the natural abundance of HMTBA, Met, and $\mathrm{CO}_{2}$.

Immediately after collection, 3-mL samples of blood, collected in airtight syringes, were analyzed for partial pressure of $\mathrm{CO}_{2}\left(\mathrm{pCO}_{2}\right)$ and $\mathrm{pH}$ with a blood gas analyzer (model IL 1306, Instrumentation Laboratory, Lexington, MA). Larger blood samples $(10 \mathrm{~mL})$ were collected in heparinized syringes and two $1-\mathrm{mL}$ blood portions were injected into evacuated vacutainers containing $1 \mathrm{~mL}$ of frozen lactic acid for measurement of $\mathrm{CO}_{2}$ enrichment (Read et al., 1984) to determine HMTBA (plus Met) oxidation across the tissues. A small portion of blood was immediately used to determine hematocrit by the microcentrifuge method. The remainder of the blood was immediately placed on ice and centrifuged $\left(15 \mathrm{~min}, 1,800 \times g\right.$ at $\left.4^{\circ} \mathrm{C}\right)$ within 30 min of collection to yield plasma. For analysis of Met, Phe, and Tyr concentrations, $1 \mathrm{~g}$ of fresh plasma was added to $0.2 \mathrm{~g}$ of an internal standard of AA labeled with stable isotopes. The internal standard solution was prepared with labeled AA diluted in water with the following concentrations: DL- $\left[1-{ }^{13} \mathrm{C}\right]$ Met $(86 \mu M)$; L- $\left[1-{ }^{13} \mathrm{C}\right]$ Phe $(247 \mu M)$; and L- $\left[{ }^{15} \mathrm{~N}\right] \mathrm{Tyr}(245 \mu M)$. 
Table 1. Composition of the TMR

\begin{tabular}{|c|c|}
\hline Item & Amount \\
\hline \multicolumn{2}{|l|}{ Ingredient, $\mathrm{g} / \mathrm{kg}$ of $\mathrm{DM}$} \\
\hline Corn silage & 244 \\
\hline Orchardgrass silage & 209 \\
\hline Micronized whole soybean & 103 \\
\hline Ground corn ${ }^{1}$ & 230 \\
\hline Ground barley $^{1}$ & 140 \\
\hline Soybean meal ${ }^{1}$ & 33 \\
\hline Molasses $^{1}$ & 12 \\
\hline Mineral and vitamin premix ${ }^{1}$ & 29 \\
\hline \multicolumn{2}{|l|}{ Estimation from NRC $(2001)^{2}$} \\
\hline $\mathrm{NE}_{\mathrm{L}}, \mathrm{Mcal} / \mathrm{kg}$ of $\mathrm{DM}$ & 1.64 \\
\hline $\mathrm{CP}, \%$ of DM & 16.5 \\
\hline RDP, g/d & 1,946 \\
\hline RUP, g/d & 1,084 \\
\hline MP, $\mathrm{g} / \mathrm{d}$ & 1,999 \\
\hline Methionine, $\%$ of MP & 1.83 \\
\hline Lysine, $\%$ of MP & 6.39 \\
\hline
\end{tabular}

${ }^{1}$ Pelleted in cubes and referred to as the concentrate.

${ }^{2}$ Calculated using feed offered during the study with chemical composition of the feed ingredients reported in Table 2.

Labeled AA (95-99 atom \%) were supplied by CDN Isotopes (Montreal, Quebec, Canada) for Met and Phe and Cambridge Isotope Laboratories (Andover, MA) for Tyr. To determine concentrations of HMTBA, another 1-g subsample of plasma was added to $0.2 \mathrm{~g}$ of unlabeled HMTBA, as described previously (Wester et al., 2006). The remainder of the plasma and the processed plasma samples were kept frozen at $-80^{\circ} \mathrm{C}$ until analyzed, whereas the processed blood samples were stored at $-20^{\circ} \mathrm{C}$.

\section{Laboratory Analyses}

Feed Ingredients and Milk. Analyses of feed ingredients and milk were performed as described previously (Martineau et al., 2007). Concentrations of AA were measured with an AA analyzer (Beckman Coulter Inc., Fullerton, CA) after a 24-h acid hydrolysis with $6 \mathrm{~N}$ phenol- $\mathrm{HCl}$ at $110^{\circ} \mathrm{C}$. A performic acid oxidation step was performed for Met and Cys before acid hydrolysis (method 994.12; AOAC, 2000).

Concentrations and Enrichments in Plasma and Milk. Concentrations of plasma Met, Phe, Tyr, and HMTBA were determined using the isotopic dilution technique (Calder et al., 1999). The concentrations and IE of plasma free HMTBA and Met were determined after deproteinization with sulfosalicylic acid and derivatization with $\mathrm{N}$-(t-butyldimethysilyl)N-methyltrifluoroacetate-(MTBSTFA):acetronile (1:1), monitoring $\mathrm{m} / \mathrm{z}$ ions 321 and 322 for HMTBA, and $\mathrm{m} / \mathrm{z}$

Table 2. Chemical composition of the feed ingredients of the diet

\begin{tabular}{|c|c|c|c|c|c|}
\hline Item & $\begin{array}{l}\text { Corn } \\
\text { silage }\end{array}$ & $\begin{array}{l}\text { Orchardgrass } \\
\text { silage }\end{array}$ & Concentrate & $\begin{array}{c}\text { Micronized } \\
\text { whole soybean }\end{array}$ & $\begin{array}{c}\text { Grass } \\
\text { hay }\end{array}$ \\
\hline \multicolumn{6}{|c|}{ Analysis, $\%$ of DM } \\
\hline $\mathrm{CP}$ & 8.5 & 14.3 & 14.8 & 50.1 & 10.2 \\
\hline $\mathrm{ADF}$ & 20.5 & 34.8 & 5.1 & 7.7 & 39.4 \\
\hline NDF & 37.3 & 55.3 & 13.1 & 16.8 & 67.9 \\
\hline Lignin & 1.7 & 3.2 & 1.8 & 1.7 & 3.7 \\
\hline $\mathrm{ADFIP}^{1}$ & 0.1 & 0.4 & 0.4 & 2.7 & 0.3 \\
\hline NDFIP $^{2}$ & 1.1 & 3.2 & 1.5 & 9.1 & 3.9 \\
\hline Ash & 3.3 & 10.4 & 9.1 & 5.5 & 6.4 \\
\hline Starch & 46.2 & 0.9 & 50.3 & 3.9 & 1.5 \\
\hline Lipid & 2.6 & 3.8 & 0.6 & 8.9 & 2.2 \\
\hline \multicolumn{6}{|c|}{ Amino acid, $\mathrm{g}$ of $\mathrm{AA} / 100 \mathrm{~g}$ of $\mathrm{CP}$} \\
\hline Alanine & 6.29 & 5.70 & 5.65 & 4.40 & 5.88 \\
\hline Arginine & 2.42 & 3.70 & 5.50 & 8.47 & 4.20 \\
\hline Aspartate & 5.68 & 7.41 & 9.14 & 12.85 & 8.93 \\
\hline Cysteine & 1.45 & 0.74 & 2.30 & 1.56 & 1.05 \\
\hline Glutamate & 12.45 & 8.00 & 20.65 & 20.39 & 8.82 \\
\hline Glycine & 3.75 & 4.96 & 4.38 & 4.47 & 4.52 \\
\hline Histidine & 1.93 & 1.56 & 2.67 & 2.80 & 1.58 \\
\hline Isoleucine & 2.90 & 3.93 & 4.01 & 4.93 & 3.68 \\
\hline Leucine & 8.59 & 6.81 & 9.36 & 8.10 & 6.62 \\
\hline Lysine & 2.18 & 3.85 & 3.79 & 6.15 & 3.89 \\
\hline Methionine & 1.69 & 1.56 & 1.56 & 1.49 & 1.58 \\
\hline Phenylalanine & 3.63 & 4.30 & 4.98 & 5.35 & 4.10 \\
\hline Proline & 6.29 & 4.37 & 8.25 & 5.51 & 5.36 \\
\hline Serine & 3.87 & 3.33 & 5.13 & 5.39 & 3.89 \\
\hline Threonine & 3.02 & 3.85 & 3.94 & 4.11 & 3.99 \\
\hline Valine & 4.23 & 5.41 & 5.72 & 5.18 & 5.46 \\
\hline Total AA & 70.37 & 69.48 & 97.03 & 101.15 & 73.53 \\
\hline
\end{tabular}

${ }^{1}$ Acid detergent-insoluble protein (ADIN multiplied by 6.25 ).

${ }^{2}$ Neutral detergent fiber insoluble protein (NDIN multiplied by 6.25 ). 
ions 320, 321, and 323 for Met by GC-MS (model GC 6890-MS 5973, Agilent Technologies, Wilmington, DE), as described previously (Calder and Smith, 1988). The IE of protein-bound Met in milk from HMTBA-treated cows was determined as performed in plasma after protein hydrolysis (approximately $10 \mathrm{mg}$ of protein hydrolyzed in $7 \mathrm{~mL}$ of $6 \mathrm{M} \mathrm{HCl}$ in sealed tubes at $110^{\circ} \mathrm{C}$ for $18 \mathrm{~h}$ with added phenol crystals and dithiothreitol, to protect aromatic amino acids and methionine, respectively, from oxidation).

The blood samples taken for determination of blood ${ }^{13} \mathrm{CO}_{2}$ IE were stored frozen on lactic acid until just before analysis, when they were thawed and reacted at room temperature, as described previously (Lapierre et al., 2002). The IE of $\mathrm{CO}_{2}$ liberated from blood was analyzed using a breath carousel coupled to an isotopic ratio mass spectrometer (SIRA 12, VG Masslab, Manchester, UK). Isotopic enrichments for Met, HMTBA, and $\mathrm{CO}_{2}$ were corrected for background abundance and expressed as mol \% excess. Concentrations of Met included the presence of labeled Met due to the infusion of labeled Met and HMTBA, whereas concentrations of HMTBA were corrected for the presence of unlabeled HMTBA.

\section{Calculations}

Net Fluxes. Net fluxes of Met and HMTBA were calculated as the product of the venoarterial concentration difference times the plasma flow of the tissue,

$$
\text { Net flux } \mathrm{tissue}=\left(C_{V}-C_{A}\right) \times \text { plasma flow }_{\text {tissue }},
$$

where the subscript to concentration $(C)$ refers to the site of sampling: $A$ for arterial, $V$ for venous. Liver net flux was estimated as the difference between splanchnic and portal fluxes.

Splanchnic plasma flows were determined from downstream dilution of $p \mathrm{AH}$ (Katz and Bergman, 1969), whereas mammary plasma flow was estimated with the Fick principle, using Phe and Tyr mammary uptake and milk concentrations of $49 \mathrm{mg}$ of Phe and $56 \mathrm{mg}$ of Tyr per g of milk CP (Swaisgood, 1995) and accounting for $3.5 \%$ of milk protein as bloodborne (Cant et al., 1993). For each tissue, negative values indicate removal and positive values release.

Methionine Kinetics. Whole-body irreversible loss rate (WB ILR) of Met was calculated as follows:

$$
W B I L R=I N F / I E_{A},
$$

where $I N F$ is the rate of infusion of $\left[\right.$ methyl $\left.-{ }^{2} \mathrm{H}_{3}\right]$ Met $\times$ IE of infusate and $I E_{A}$ represents the IE of the chosen precursor pool, plasma arterial free Met. The IE of plasma free Met was calculated as the arithmetic mean of samples taken between 4 to $8 \mathrm{~h}$ of infusion, which were at plateau enrichment.

The ILR of Met across each tissue studied was calculated as the difference in isotope exchange divided by the IE of the precursor pool to convert label transfers into total movements of Met as follows:

$$
\begin{gathered}
I L R_{\text {tissue }}=\left[\left(C_{V} \times I E_{V}\right)-\left(C_{A} \times I E_{A}\right)\right] \\
\times \text { plasma flow }_{\text {tissue }} / I E_{p p},
\end{gathered}
$$

where $I E_{p p}$ is the IE of the appropriate precursor pool, taken as $\left[\right.$ methyl- $\left.^{2} \mathrm{H}_{3}\right]$ Met in the venous drainage of each tissue. Because the IE of the arterial Met was always higher than the IE of the Met in the venous plasma used for the calculation of the ILR through the tissues, the summation of the ILR of individual tissues was higher than the estimation of the whole-body ILR. Therefore, for comparison of the relative contributions of the various organs to whole-body metabolism, values were calculated based on ${ }^{13} \mathrm{C}$ transfers; this is the same as applying a common, but unspecified, precursor to all sites.

Contribution of HMTBA to Met Kinetics. The contributions that HMTBA can make to WB Met ILR were assessed by 2 different approaches:

(a) The fraction of plasma Met flux derived from HMTBA (IE ${ }^{13} \mathrm{C}-$ Met:IE ${ }^{13} \mathrm{C}-\mathrm{HMTBA}$ times WB Met ILR, based on the $\left[{ }^{2} \mathrm{H}_{3}\right]$ Met infusion) estimates the amount of Met synthesized within tissues and released into the blood circulation. This calculation yields a minimum estimate, as no allowance is made for Met synthesized and used within cells and for the fact that plasma-based estimates of ILR are minimum values.

(b) The difference between whole-body ILR of Met between the HMTBA-infused and the control cows. This combines HMTBA converted to Met and exported into blood circulation plus the effect on endogenous (unlabeled) Met (e.g., synthesis of labeled Met from labeled HMTBA may be used to support intracellular processes, such as protein synthesis, or production of other metabolites, such as homocysteine and polyamines, and this spares Met released from protein breakdown that is then exported to plasma for use by other tissues, including the mammary gland, MG). In quantitative terms, this approach contains an overestimation because the HMTBA infusion may increase protein synthesis and degradation, but underestimations also arise due to the use of plasma-based ILR.

The contribution of HMTBA to Met kinetics across tissues also can be estimated through the concomitant 
infusion of ${ }^{2} \mathrm{H}_{3}$-Met and ${ }^{13} \mathrm{C}$-HMTBA. This dual-label approach, based on principles defined elsewhere (Biolo et al., 1995), has been refined to include the contribution of HMTBA (Lobley et al., 2006b) and assumes that inward and outward transport, protein synthesis and degradation, plus synthesis de novo, go to or derive from a common intracellular pool. Briefly, and as described previously (Lobley et al., 2006b), this model predicts, based on $\left[{ }^{2} \mathrm{H}_{3}\right]$ Met kinetics, the enrichment of $\left[1-{ }^{13} \mathrm{C}\right]$ Met in the tissue venous drainage, or milk, in the case of the MG, in the absence of any synthesis in situ from $\left[1-{ }^{13} \mathrm{C}\right]$ HMTBA. The difference between predicted and observed $\left[1-{ }^{13} \mathrm{C}\right]$ Met enrichments estimates the amount synthesized in situ from $\left[1-{ }^{13} \mathrm{C}\right]$ HMTBA. Equations for the various model approaches have been detailed previously (Zuur et al., 2002; Lobley et al., 2006b). This model assumes that the change in the ratio $\left[{ }^{13} \mathrm{C}\right]:\left[\right.$ methyl- $\left.{ }^{2} \mathrm{H}_{3}\right]$ Met only occurs through synthesis of $\left[1-{ }^{13} \mathrm{C}\right]$ Met from labeled HMTBA and not through altered [methyl- $\left.{ }^{2} \mathrm{H}_{3}\right]$ Met enrichment via intracellular Met cycle activity. This assumption appears valid for sheep, at least across the splanchnic tissues (Lobley et al., 1996). Because no splanchnic tissue samples were available to determine the IE of the intracellular pool, a simpler model was adopted based on the assumption that all of the arterial inflow of Met passes through the intracellular pool with calculation based on the ratios of $\left[1-{ }^{13} \mathrm{C}\right]$ Met: $\left[{ }^{2} \mathrm{H}_{3}\right]$ Met in the plasma inflow $\left(\mathrm{R}_{\mathrm{i}}\right)$ and outflow $\left(\mathrm{R}_{\mathrm{o}}\right)$, the latter assumed equivalent to the tissue intracellular pool (Lobley et al., 2006b). With these assumptions, appearance of newly synthesized Met $(\mathrm{mmol} / \mathrm{h})$ in the venous outflow was estimated as $\left(\mathrm{R}_{\mathrm{o}} / \mathrm{R}_{\mathrm{i}}-1\right) \times$ arterial $\left[1-{ }^{13} \mathrm{C}\right]$ Met flow $(\mathrm{mmol} / \mathrm{h})$. For mammary metabolism, however, milk enrichment was used as representative of the intracellular pool and this allowed the full model to be solved (Zuur et al., 2002; Lobley et al., 2006b). The model was further refined to take into account inconsistencies between predicted and observed ${ }^{13} \mathrm{C}$ IE of milk. Possible reasons for these inconsistencies (lower enrichment in milk than in the intracellular pool) include the $0.5 \mathrm{~h}$ taken for polypeptides to be translated, processed, and secreted from mammary cells or incomplete previous milking, or both (Zuur et al., 2002).

The half-life of HMTBA was calculated from steadystate kinetics, where rate of disappearance was equal to the rate of infusion and with the assumption that the pool size was equal to arterial plasma concentration times body water (estimated as $\mathrm{BW} \times 0.65$ ); therefore, half-life $=$ pool size $\times \ln (2) /$ infusion rate of HMTBA. Oxidation of HMTBA across the splanchnic tissues (TSP) and the MG (including labeled Met) was calculated as previously reported (Lapierre et al., 2002).

\section{Statistical Analysis}

Metabolite concentrations, net flux, and kinetics data were averaged by cow for each period for statistical analysis. Dry matter intake, milk yield, and milk composition were averaged over the last day of each period. All data were statistically analyzed using the GLM procedure of SAS (SAS Institute., 1999) with cow, treatment, and period as the main effects. Differences were considered significant if $P \leq 0.05$ and as a trend for $0.05<P \leq 0.10$. Data are reported as least squares means with pooled standard error of the means, unless otherwise stated.

\section{RESULTS}

The DMI was fixed slightly below ad libitum intake through the trial and, therefore, was not affected by treatment, averaging 17.4 vs. $17.9 \pm 0.3$ for control versus HMTBA cows, respectively. The infusion of HMTBA had no effect $(P>0.20)$ on milk production and composition (Table 3). Plasma flows across tissues were not affected $(P>0.10)$ by treatments and averaged 1,369 vs. $1,335 \pm 40 \mathrm{~L} / \mathrm{h}, 1,547$ vs. $1,543 \pm 6 \mathrm{~L} / \mathrm{h}$, and 660 vs. $585 \pm 18 \mathrm{~L} / \mathrm{h}$ for portal, splanchnic, and mammary beds, respectively.

\section{HMTBA and Methionine Net Fluxes}

No HMTBA was detected in arterial plasma during the control period, but averaged $35.0 \mu M$ during HMTBA infusion. The IE of HMTBA slightly increased $(P<0.01)$ during the blood sampling period, from 93.6 to $98.4 \pm 0.3 \mathrm{~mol} \%$ excess, but the last 3 values were similar. The portal-drained viscera (PDV), the liver and the MG removed 1.0, 3.2, and $0.3 \mathrm{mmol}$ of HMTBA/h, respectively (Table 4). Liver extraction represented $6.1 \pm 0.4 \%$ of the total hepatic inflow of HMTBA. Labeled $\mathrm{CO}_{2}$ appearance across the splanchnic and the mammary tissues represented $0.8 \pm 0.1$ and $0.2 \pm 0.02 \mathrm{mmol} / \mathrm{h}$ of HMTBA (11 and $3 \%$ of the infused dose, respectively). These values represent a combination of oxidation of both HMTBA directly and $\left[{ }^{13} \mathrm{C}\right]$ Met synthesized from HMTBA. No oxidation of ${ }^{13} \mathrm{C}$ compounds was detected across the PDV (data not shown). The half-life of HMTBA was estimated at $70 \pm 5$ min.

Infusion of HMTBA increased $(P<0.01)$ arterial Met concentrations (Table 5). Extraction of HMTBA by the tissues always exceeded estimated oxidation, which would indicate potential intracellular transformation into Met. Nonetheless, tissue extraction of HMTBA did not increase Met net fluxes. Indeed, whereas net 
Table 3. Effect of 2-hydroxy-4-methylthiobutanoate (HMTBA) infusion on milk production and composition in dairy cows ${ }^{1}$

\begin{tabular}{|c|c|c|c|c|}
\hline \multirow[b]{2}{*}{ Milk } & \multicolumn{2}{|c|}{ Treatment } & \multirow[b]{2}{*}{ SEM } & \multirow[b]{2}{*}{$P$-value 2} \\
\hline & Control & HMTBA & & \\
\hline Production, kg/d & 31.0 & 31.6 & 0.9 & 0.67 \\
\hline Protein yield, g/d & 978 & 1,031 & 23 & 0.24 \\
\hline Protein concentration, \% & 3.18 & 3.29 & 0.05 & 0.22 \\
\hline Fat yield, $\mathrm{g} / \mathrm{d}$ & 1,300 & 1,353 & 108 & 0.76 \\
\hline Fat concentration, $\%$ & 4.29 & 4.26 & 0.39 & 0.96 \\
\hline
\end{tabular}

${ }^{1}$ Least squares means presented with pooled standard error of the means, $\mathrm{n}=4$.

${ }^{2}$ Probability corresponding to the null hypothesis of no treatment effect.

portal and mammary fluxes of Met were unaffected $(P>0.15)$ by HMTBA infusion, net Met removal by the liver actually increased $(P=0.02)$, resulting in decreased $(P<0.01)$ post-liver supply of Met from 7.0 to $2.9 \mathrm{mmol} / \mathrm{h}$ between control and HMTBA infusion, respectively (Table 5). Net Met extraction by the MG was not affected by treatment.

\section{Irreversible Loss Rate of Methionine}

Whole-body ILR of Met increased by $36 \%(P=0.03)$ when the cows were infused with HMTBA (Table 5). Met ILR across the liver and the MG were also elevated $(P=0.03)$, by 82 and $21 \%$, respectively with HMTBA infusion, whereas the ILR across the PDV remained unchanged (Table 5). The proportion of WB ILR of Met removed by the TSP and mammary tissues was increased $(P<0.05)$ with HMTBA infusion, averaging 0.53 vs. $0.75 \pm 0.02$ and 0.42 versus $0.37 \pm 0.01$, for the control versus HMTBA-treated cows, respectively.

\section{Contribution of HMTBA to Met Flux}

Whole-Body Kinetics. Infusion of $8.79 \mathrm{mmol} / \mathrm{h}$ of $\left[{ }^{13} \mathrm{C}\right]$ HMTBA increased the WB ILR of Met by $6.5 \mathrm{mmol} / \mathrm{h}$ [calculation method (b)]. This represents endogenous Met released from intracellular protein breakdown and spared from use for cellular processes within the tissue plus Met formed from HMTBA and released into blood circulation. The $\left[{ }^{13} \mathrm{C}\right]$ Met derived directly from HMTBA represented $15 \%$ of plasma Met ILR (Table 6), equal to $3.8 \mathrm{mmol} / \mathrm{h}$ [calculation method (a)]. This value represents a minimum estimate of the conversion of the HMTBA infused into Met, as 1) WB ILR of Met estimated from the isotopic enrichment of the infused amino acid in the artery is a minimum estimate and 2) the ${ }^{13} \mathrm{C}$ enrichment of circulating Met does not account for Met formed within tissues and not exported to blood.

Tissue Kinetics. The altered ${ }^{13} \mathrm{C}-\mathrm{Met}:{ }^{2} \mathrm{H}_{3}$ Met ratio between the outflow and inflow across the splanchnic tissues (Table 6) allowed estimation of the minimum contribution of HMTBA to Met synthesis within these tissues. Assuming no bypass of blood circulation across the TSP bed and, therefore, yielding minimal estimates of HMTBA utilization for Met synthesis, $1.7 \mathrm{mmol} / \mathrm{h}$ of HMTBA would have been used for Met synthesis across the splanchnic bed, $0.4 \mathrm{mmol} / \mathrm{h}$ across the PDV, and $1.2 \mathrm{mmol} / \mathrm{h}$ across the liver. From this intracellular synthesis, $1.5 \mathrm{mmol} / \mathrm{h}$ of newly synthesized Met would have been released into blood circulation.

The synthesis of Met from HMTBA in the MG averaged $0.3 \mathrm{mmol} / \mathrm{h}$, of which approximately $0.2 \mathrm{mmol} / \mathrm{h}$ was secreted in milk protein. Overall, however, $15 \%$ of Met in milk protein originated directly from HMTBA $(1.3 \mathrm{mmol} / \mathrm{h})$, so the largest amount $(1.1 \mathrm{mmol} / \mathrm{h})$ was derived from Met synthesized from HMTBA in other tissues, released into the blood circulation and then taken up by the MG.

\section{DISCUSSION}

\section{Whole Body}

Reported effects of HMTBA provision on milk production and composition are variable (Polan et al., 1970; Piepenbrink et al., 2004; St-Pierre and Sylvester, 2005). Such variation may reflect differences in the amount absorbed or the responsiveness of the cows to

Table 4. Concentration and kinetics of 2-hydroxy-4-methylthiobutanoate (HMTBA) in cows infused with HMTBA

\begin{tabular}{lcc}
\hline Item & HMTBA & SEM \\
\hline Arterial concentration, $\mu M$ & 35.0 & 2.5 \\
Net flux, mmol/h & -1.0 & 0.1 \\
$\quad$ Portal & -3.2 & 0.4 \\
Hepatic & -4.2 & 0.4 \\
Splanchnic & -0.3 & 0.1 \\
Mammary & & \\
Oxidation, ${ }^{1}$ mmol/h & 0.8 & 0.14 \\
Splanchnic & 0.2 & 0.02 \\
Mammary
\end{tabular}

${ }^{1}$ Includes HMTBA oxidation plus oxidation of ${ }^{13} \mathrm{C}$-methionine. 
Table 5. Effect of 2-hydroxy-4-methylthiobutanoate (HMTBA) infusion on Met kinetics across tissues in dairy cows $^{1}$

\begin{tabular}{|c|c|c|c|c|}
\hline \multirow[b]{2}{*}{ Item } & \multicolumn{2}{|c|}{ Treatment } & \multirow[b]{2}{*}{ SEM } & \multirow[b]{2}{*}{$P$-value ${ }^{2}$} \\
\hline & Control & HMTBA & & \\
\hline Arterial concentration, $\mu M$ & 19.7 & 53.4 & 3.9 & $<0.01$ \\
\hline \multicolumn{5}{|l|}{ Net flux, $\mathrm{mmol} / \mathrm{h}$} \\
\hline Portal & 9.4 & 10.8 & 0.5 & 0.16 \\
\hline Hepatic & -2.4 & -7.9 & 0.6 & 0.02 \\
\hline Splanchnic & 7.0 & 2.9 & 0.3 & $<0.01$ \\
\hline Mammary & -7.3 & -7.3 & 0.2 & 0.66 \\
\hline Milk & -7.6 & -8.1 & 0.2 & 0.23 \\
\hline \multicolumn{5}{|c|}{ Irreversible loss rate (ILR), $\mathrm{mmol} / \mathrm{h}^{3}$} \\
\hline Whole body & 17.9 & 24.4 & 0.5 & $<0.01$ \\
\hline Portal & -8.1 & -8.7 & 1.3 & 0.79 \\
\hline Hepatic & -8.7 & -15.8 & 0.8 & 0.03 \\
\hline Splanchnic & -16.8 & -24.5 & 0.5 & $<0.01$ \\
\hline Mammary & -8.1 & -9.9 & 0.2 & 0.03 \\
\hline
\end{tabular}

additional Met. The question of absorption was not addressed in the current study, as the HMTBA was provided as a vascular infusion. Furthermore, with the small number of animals used, the objective was not to test productive performance and the slight increments observed for milk protein concentration and yield remained numerical.

The current study did provide, however, clear answers on the metabolic fate of HMTBA, once within the blood circulation. The half-life of HMTBA averaged $70 \mathrm{~min}$, within the range of previous observations in cows (70 min; Lapierre et al., 2007) and sheep (76 min; Lobley et al., 2006b). At the whole-body level, HMTBA infusion increased Met availability, between 3.8 and $6.5 \mathrm{mmol} / \mathrm{h}$, depending on the calculation method used, providing an additional 13 to $23 \mathrm{~g} / \mathrm{d}$ of Met. Therefore, between 43 and $74 \%$ of the dose of HMTBA infused would have been converted into Met and released into the blood circulation. As already mentioned, these calculations probably represent underestimates, so although uncertainties remain about the absolute quantitative transfer of HMTBA into Met, it is clear that absorbed HMTBA contributes markedly to Met supply. The current data are similar to observations in sheep, where at least $55 \%$ of HMTBA infused into the mesenteric vein was converted to Met (Lobley et al., 2006a). With this point firmly established, the second question is: where does this conversion happen?

Table 6. Effect of 2-hydroxy-4-methylthiobutanoate (HMTBA) infusion on isotopic enrichment (mol \% excess) of Met in dairy cows during an infusion of $\left[{ }^{2} \mathrm{H}_{3}\right]$ Met and with the infusion of HMTBA switched to $\left[1-{ }^{13} \mathrm{C}\right]$ HMTBA $^{1}$

\begin{tabular}{|c|c|c|c|c|c|c|}
\hline \multirow[b]{3}{*}{ Site } & \multicolumn{4}{|c|}{$\left[{ }^{2} \mathrm{H}_{3}\right] \mathrm{Met}$} & \multirow{2}{*}{$\frac{\left[{ }^{13} \mathrm{C}\right] \mathrm{Met}}{\text { Treatment }}$} & \multirow{2}{*}{$\frac{{ }^{13} \mathrm{C} /{ }^{2} \mathrm{H}_{3} \text { Met }}{\text { Treatment }}$} \\
\hline & \multicolumn{2}{|c|}{ Treatment } & \multirow[b]{2}{*}{ SEM } & \multirow[b]{2}{*}{$P$-value ${ }^{2}$} & & \\
\hline & Control & HMTBA & & & HMTBA & HMTBA \\
\hline Artery & $7.34^{\mathrm{a} *}$ & $5.38^{\mathrm{a}}$ & 0.15 & 0.02 & $15.5^{\mathrm{a}}$ & $2.90^{\mathrm{a} *}$ \\
\hline Portal vein & $4.43^{\mathrm{b}}$ & $4.19^{c}$ & 0.14 & 0.36 & $12.6^{\mathrm{bc}}$ & $3.02^{\mathrm{a} *}$ \\
\hline Hepatic vein & $4.10^{\mathrm{b}}$ & $4.00^{\mathrm{c}}$ & 0.08 & 0.45 & $13.1^{\mathrm{b}}$ & $3.28^{\mathrm{b}}$ \\
\hline Mammary vein & $6.91^{\mathrm{a} *}$ & $4.94^{\mathrm{b}}$ & 0.16 & 0.02 & $15.5^{\mathrm{a}}$ & $3.14^{\mathrm{c}}$ \\
\hline Milk & - & $3.55^{\mathrm{d}}$ & - & - & $12.1^{\mathrm{c}}$ & $3.41^{\mathrm{d}}$ \\
\hline SEM & 0.11 & 0.07 & & & 0.19 & 0.026 \\
\hline$P$-value ${ }^{3}$ & 0.001 & 0.001 & & & 0.001 & 0.001 \\
\hline
\end{tabular}

\footnotetext{
${ }^{\mathrm{a}-\mathrm{d}}$ Values with different superscripts within a column are different $(P<0.05)$.

${ }^{1}$ Least squares means presented with pooled standard error of the means, $\mathrm{n}=4$.

${ }^{2}$ Probability corresponding to the null hypothesis of no treatment within each site.

${ }^{3}$ Probability corresponding to the null hypothesis for a site effect within each treatment.

*Values within a column differ at $P<0.10$.
} 


\section{Sites of Synthesis of Met from HMTBA}

Both the PDV and the liver (see below) have the capacity to simultaneously utilize and produce Met. Net removal of both $\left[{ }^{2} \mathrm{H}_{3}\right]$ and $\left[{ }^{13} \mathrm{C}\right]$ Met occurs across both tissues, compatible with systemic supply of the amino acid to support both tissue protein synthesis and as part of the catabolic process to maintain stable plasma concentrations of Met. In the absence of any synthesis of Met from HMBTA, the ratio of ${ }^{13} \mathrm{C}^{2} \mathrm{H}_{3}$ Met would remain constant between the vascular inflow and outflow to these tissues (i.e., the fractional removal of both $\left[{ }^{2} \mathrm{H}_{3}\right]$ and $\left[{ }^{13} \mathrm{C}\right]$ Met would be similar). In practice, the ${ }^{13} \mathrm{C}^{2} \mathrm{H}_{3}$ Met increased, indicating that in both tissues synthesis of Met from HMTBA occurred.

Portal-Drained Viscera. Portal removal of HMTBA from the systemic circulation averaged $11 \%$ of the dose infused, similar to observations in sheep, where only $87 \%$ of HMTBA supplied to the abomasum was recovered in the portal vein (Lobley et al., 2006a). As oxidation of HMTBA (and synthesized Met) was not detected across the PDV, then most of that extracted was probably used to support Met synthesis. Such synthesis has been reported in sheep (Lobley et al., 2006b) and both the omasal and ruminal epithelia contain the enzymes necessary for the conversion of $\mathrm{D}$ - and L-HMTBA into 2-keto-4-methylthiobutanoate (McCollum et al., 2000). Direct support for a similar fate in the current dairy cows comes from 2 findings. First, a numerical increase $(1.4 \mathrm{mmol} / \mathrm{h})$ occurred in apparent net portal absorption of Met when HMTBA was provided. Second, the ratio of ${ }^{13} \mathrm{C}:{ }^{2} \mathrm{H}_{3}$ Met was greater $(P<0.10)$ in the portal vein compared with that in the artery and this would equate to $0.4 \mathrm{mmol} / \mathrm{h}$ of Met synthesized from HMTBA and exported to plasma. This is a minimal value because the model adopted assumes all the arterial inflow of Met passes through the tissue intracellular pool. The underestimate obtained probably explains why the value is lower than those based on either net Met transfers across the PDV or observed directly in sheep (Lobley et al., 2006b). Furthermore, part of the synthesized Met is probably retained within constitutive proteins. Indeed, slightly less than half of the Met synthesized from HMTBA within the PDV tissues of sheep was released into the portal circulation, with the rest retained within cellular proteins (Lobley et al., 2006b). Nonetheless, this additional source of Met had no effect on Met ILR across the PDV, suggesting that no increment in either protein synthesis or oxidation of Met (as partly monitored though ${ }^{13} \mathrm{CO}_{2}$ production) occurred in the current cows.

Liver. Liver extraction of HMTBA averaged $38 \%$ of the dose infused. This is similar to previous values from dairy cows, where hepatic removal represented $34 \%$ of the portal appearance following ingestion of either 12.5 or $25 \mathrm{~g}$ of Alimet (Novus International Inc.), but where HMTBA concentrations in plasma were lower (Lapierre et al., 2007). In sheep, liver removal of HMTBA varied between 25 and $37 \%$ of net portal appearance over a wide range of arterial concentrations (12 to $114 \mu \mathrm{M}$; Lobley et al., 2006a; Wester et al., 2006).

As to the fate of the $3.2 \mathrm{mmol} / \mathrm{h}$ of HMTBA removed by the liver of the current cows, $0.8 \mathrm{mmol} / \mathrm{h}$ was oxidized, with $2.4 \mathrm{mmol} / \mathrm{h}$ potentially available for Met synthesis, although no increase in net hepatic release of Met occurred. This agrees with previous studies in chickens (Wang et al., 2001) and sheep (Wester et al., 2006) in which liver removal of HMTBA also failed to produce additional net release of Met. In dairy cows not supplemented with HMTBA, net release of Met across the splanchnic tissues matched both uptake by the MG and net export in milk protein (Lobley and Lapierre, 2003; Lapierre et al., 2005) and this was also observed for the control treatment in the current study. Beyond these needs for milk protein synthesis, any surplus Met, either supplied from the diet or synthesized from HMTBA within nonhepatic tissues, will be catabolized by the liver. This catabolism is probably triggered by increased Met plasma concentrations and hepatic inflow (Lobley and Lapierre, 2003). Indeed, hepatic fractional extraction of Met did not change in response to HMTBA-induced increases in Met concentrations and hepatic inflow in sheep (10-11\%; Wester et al., 2006) and in the current dairy cows $(6.1-8.6 \%)$.

No increase in net Met release from the liver during HMTBA provision does not preclude Met hepatic synthesis and release into the blood circulation. This is clearly demonstrated by the increased ratio of ${ }^{13} \mathrm{C}:{ }^{2} \mathrm{H}_{3}$ Met across the liver, such that although net removal of Met by the liver increased more than 3-fold when HMTBA was supplied, a minimum of $1.1 \mathrm{mmol} / \mathrm{h}$ of Met derived from hepatic HMTBA was released into the postsplanchnic circulation. In consequence, the liver contributed between 20 and $35 \%$ of the plasma Met that directly arose from HMTBA. Furthermore, based on hepatic uptake and maximal oxidation of HMTBA of 3.2 and $0.8 \mathrm{mmol} / \mathrm{h}$, respectively, then a further $1.3 \mathrm{mmol} / \mathrm{h}$ of Met synthesized within the liver was used to support constitutive and export protein synthesis. These data illustrate the key role played by the liver in regulation of overall Met kinetics, with the vital function to maintain plasma aminoacidemia through a balance between Met removal and synthesis from HMTBA.

In fattening sheep, where the metabolic demand for Met is much lower than in the high-yielding dairy cow, provision of HMTBA led to such high rates of Met removal by the liver that net splanchnic release of 
Met became negative (Lobley et al., 2006a; Wester et al., 2006). In the current study, net splanchnic release remained positive but was clearly insufficient $(-5.2$ $\mathrm{mmol} / \mathrm{h}$ ) to cover milk protein secretion. Inevitably this means that postsplanchnic tissues must then provide the Met required to support milk protein synthesis, this may also include a direct contribution from the MG.

Mammary Gland. The MG extracted only a limited amount of HMTBA $(0.3 \mathrm{mmol} / \mathrm{h})$, of which 0.2 $\mathrm{mmol} / \mathrm{h}$ was converted into Met used for milk protein secretion, with the remainder used for either synthesis of constitutive protein or oxidized. In addition, 1.1 mmol of Met/h synthesized from Met in other tissues and released into the blood circulation was extracted by the MG. The tissue source of this Met synthesized from HMTBA cannot be identified precisely but, besides the contribution of the TSP, estimated at $0.4 \mathrm{mmol} / \mathrm{h}$, the remainder $(0.7 \mathrm{mmol} / \mathrm{h})$ probably originated from the kidneys, as shown in sheep (Lobley et al., 2006a, b). The total of $1.3 \mathrm{mmol}$ of Met/h that directly originated from HMTBA was insufficient to cover the deficit between post-liver supply of Met $(2.9 \mathrm{mmol} / \mathrm{h})$ and Met in milk protein secretion $(8.1 \mathrm{mmol} / \mathrm{h})$. This shortfall must be met from unlabeled sources of Met, notably that from protein breakdown within extra-splanchnic tissues and not reused to support protein synthesis, as this function will be provided by the additional Met produced from intracellular metabolism of HMTBA. The Met released from protein breakdown will then be exported from the tissues and become available to the MG to support milk synthesis.

\section{CONCLUSIONS}

Altogether, these data illustrate the metabolic flexibility of the dairy cow to respond to either direct or indirect changes in AA supply. Approximately $15 \%$ of Met incorporated into milk protein originated from direct conversion of HMTBA to Met. Of this, 33\% was derived from splanchnic tissue metabolism, whereas $15 \%$ occurred in the $\mathrm{MG}$ and the remainder (52\%) arose from peripheral tissue conversions. Indirect metabolism provided the remainder (85\%) where Met synthesized from HMTBA within tissues was used to support intracellular protein synthesis, and this allowed Met released from protein breakdown to be exported for use by the MG. To ensure maintenance of aminoacidemia and prevent Met toxicity the liver plays a key role through simultaneous removal of Met and hepatic synthesis from HMTBA. Based on the current data and those from the ovine (Lobley et al., 2006a), the majority of HMTBA available to body tissues is converted to Met, rather than being catabolized, so that even limited availability from the diet could still provide sufficient Met to support productive processes.

\section{ACKNOWLEDGMENTS}

The authors gratefully thank the staff of the Dairy and Swine Research \& Development Centre for taking care of the animals, M. Léonard and J. Renaud (Agriculture and Agri-Food Canada, Sherbrooke, Quebec, Canada) for their dedicated technical support, as well as S. Méthot (Agriculture and Agri-Food Canada, Sherbrooke, Quebec, Canada) for statistical analyses. Appreciation is extended to Novus International (St. Louis, MO) and Agriculture and Agri-Food Canada (Sherbrooke, Quebec, Canada) for their financial support.

\section{REFERENCES}

AOAC. 2000. Official Methods of Analysis. 17th ed. William Horwitz, ed. Washington, DC.

Belasco, I. J. 1972. Stability of methionine hydroxy analog in rumen fluid and its conversion in vitro to methionine by calf liver and kidney. J. Dairy Sci. 55:353-357.

Biolo, G., R. Y. D. Fleming, S. P. Maggi, and R. R. Wolfe. 1995 Transmembrane transport and intracellular kinetics of amino acids in human skeletal muscle. Am. J. Physiol. 268:E75-E84.

Calder, A. G., K. E. Garden, S. E. Anderson, and G. E. Lobley. 1999. Quantitation of blood and plasma amino acids using isotope dilution electron impact gas chromatography/mass spectrometry with $\mathrm{U}^{13} \mathrm{C}$ amino acids as internal standards. Rapid Commun. Mass Spectrom. 13:2080-2083.

Calder, A. G., and A. Smith. 1988. Stable isotope ratio analysis of leucine and ketoisocaproic acid in blood plasma by gas chromatography/mass spectrometry. Use of tertiary butyldimethylsilyl derivatives. Rapid Commun. Mass Spectrom. 2:14-16.

Cant, J. P., E. J. DePeters, and R. L. Baldwin. 1993. Mammary amino acid utilization in dairy cows fed fat and its relationship to milk protein depression. J. Dairy Sci. 76:762-774.

Dibner, J. J. 2003. Review of the metabolism of 2-hydroxy-4(methylthio) butanoic acid. World's Poult. Sci. J. 59:99-110.

Dibner, J. J., and F. J. Ivey. 1992. Capacity in the liver of the broiler chick for conversion of supplemental methionine activity to L-methionine. Poult. Sci. 71:700-708.

Dibner, J. J., and C. D. Knight. 1984. Conversion of 2-hydroxy-4(methylthio)butanoic acid to L-methionine in the chick: A stereospecific pathway. J. Nutr. 114:1716-1723.

Huntington, G. B., C. K. Reynolds, and B. H. Stroud. 1989. Techniques for measuring blood flow in splanchnic tissues of cattle. J. Dairy Sci. 72:1583-1595.

Katz, M. L., and E. N. Bergman. 1969. Hepatic and portal metabolism of glucose, free fatty acids, and ketone bodies in the sheep. Am. J. Physiol. 216:953-960.

Koenig, K. M., L. M. Rode, C. D. Knight, and P. R. McCullough 1999. Ruminal escape, gastrointestinal absorption, and response of serum methionine to supplementation of liquid methionine hydroxy analog in dairy cows. J. Dairy Sci. 82:355-361.

Koenig, K. M., L. M. Rode, C. D. Knight, and M. Vazquez-Anon. 2002. Rumen degradation and availability of various amounts of liquid methionine hydroxy analog in lactating dairy cows. J. Dairy Sci. 85:930-938.

Lapierre, H., R. Berthiaume, G. Raggio, M. C. Thivierge, L. Doepel, D. Pacheco, P. Dubreuil, and G. E. Lobley. 2005. The route of absorbed nitrogen into milk protein. Anim. Sci. 80:11-22. 
Lapierre, H., J. P. Blouin, J. F. Bernier, C. K. Reynolds, P. Dubreuil, and G. E. Lobley. 2002. Effect of supply of metabolizable protein on whole body and splanchnic leucine metabolism in lactating dairy cows. J. Dairy Sci. 85:2631-2641.

Lapierre, H., M. Vázquez-Añón, D. Parker, P. Dubreuil, and G. E. Lobley. 2007. Short communication: Absorption of 2-hydroxy-4methylthiobutanoate in dairy cows. J. Dairy Sci. 90:2937-2940.

Lobley, G. E., A. Connell, and D. Revell. 1996. The importance of transmethylation reactions to methionine metabolism in sheep: Effects of supplementation with creatine and choline. Br. J. Nutr. $75: 47-56$.

Lobley, G. E., and H. Lapierre. 2003. Post-absorptive metabolism of amino acids. Pages 737-756 in Progress in Research on Energy and Pprotein Metabolism. W. B. Souffrant and C. C. Metges, ed. EAAP publication No.109. Wageningen Academic Publishers, Wageningen, the Netherlands.

Lobley, G. E., T. J. Wester, A. G. Calder, D. S. Parker, J. J. Dibner, and M. Vazquez-Anon. 2006a. Absorption of 2-hydroxy-4-methylthiobutyrate and conversion to methionine in lambs. J. Dairy Sci. 89:1072-1080.

Lobley, G. E., T. J. Wester, G. Holtrop, J. J. Dibner, D. S. Parker, and M. Vázquez-Añón. 2006b. Absorption and digestive tract metabolism of 2-hydroxy-4-methylthiobutanoic acid in lambs. J. Dairy Sci. 89:3508-3521.

Martineau, R., H. Lapierre, D. R. Ouellet, D. Pellerin, and R. Berthiaume. 2007. Effects of the method of conservation of timothy on nitrogen metabolism in lactating dairy cows. J. Dairy Sci. 90:2870-2882.

McCollum, M. Q., M. Vázquez-Añón, J. J. Dibner, and K. E. Webb Jr.. 2000. Absorption of 2-hydroxy-4-(methylthio)butanoic acid by isolated sheep ruminal and omasal epithelia. J. Anim. Sci. 78:1078-1083.

Noftsger, S., N. R. St-Pierre, and J. T. Sylvester. 2005. Determination of rumen degradability and ruminal effects of three sources of methionine in lactating cows. J. Dairy Sci. 88:223-237.
NRC. 2001. Nutrient Requirements of Dairy Cattle. 7th ed. Natl. Acad. Press, Washington, DC.

Piepenbrink, M. S., A. L. Marr, M. R. Waldron, W. R. Butler, T. R. Overton, M. Vázquez-Añón, and M. D. Holt. 2004. Feeding 2-hydroxy-4-(methylthio)-butanoic acid to periparturient dairy cows improves milk production but not hepatic metabolism. J. Dairy Sci. 87:1071-1084

Polan, C. E., P. T. Chandler, and C. N. Miller. 1970. Methionine hydroxy analog: Varying levels for lactating cows. J. Dairy Sci. 53:607-610.

Read, W. W., M. A. Read, M. J. Rennie, R. C. Griggs, and D. Halliday. 1984. Preparation of $\mathrm{CO}_{2}$ from blood and protein-bound amino acid carboxyl groups for quantification of ${ }^{13} \mathrm{C}$-isotope measurements. Biol. Mass Spectrom. 11:348-352.

SAS Institute. 1999. SAS System for Mixed Models. SAS Institute Inc., Cary, NC.

St-Pierre, N. R., and J. T. Sylvester. 2005. Effects of 2-hydroxy-4(methylthio) butanoic acid (HMB) and its isopropyl ester on milk production and composition by Holstein cows. J. Dairy Sci. 88:2487-2497.

Swaisgood, H. E. 1995. Protein and amino acid composition of bovine milk. Pages 464-468 in Handbook of Milk Composition. R. G. Jensen., ed. Academic Press, Toronto, Ontario, Canada.

Wang, S., W. G. Bottje, Z. Song, K. Beers, M. Vazques-Añon, and J. J. Dibner. 2001. Uptake of DL-2-hydroxy-4-methylthio-butanoic acid (DL-HMB) in the broiler liver in vivo. Poult. Sci. 80:1619-1624.

Wester, T. J., M. Vázquez-Añón, J. Dibner, D. S. Parker, A. G. Calder, and G. E. Lobley. 2006. Hepatic metabolism of 2-hydroxy-4-methylthiobutyrate in growing lambs. J. Dairy Sci. 89:1062-1071.

Zuur, G., G. E. Lobley, M. Vázquez-Añón, and H. Lapierre. 2002. A tracer kinetic model for metabolism of 2-hydroxy-4-[methylthio]butanoic acid (HMB) by the mammary gland of lactating cows. J. Agric. Sci. (Camb) 139:106-107. 